\title{
Livestock grazing impacts on infiltration rates in a temperate range of Pakistan
}

\author{
FAIZUL BARI, M. KARL WOOD, AND LEIGH MURRAY
}

Authors are former graduate student and professor, Dept. of Animal and Range Sciences; and associate professor, Dept. of Experimental Statistics, New Mexico State University, Las Cruces 88003.

\section{Abstract}

This study was conducted in a temperate range of northern Pakistan in 1987 and 1988. The main purpose of the experiment was to determine a suitable residual phytomass level for the moist temperate ranges of Pakistan. Data were collected for 2 consecutive growing seasons. A completely randomized design, with 4 treatments and 2 replications, was used. The treatments were 4 different residual phytomass levels. A rainfall simulator applied rainfall to 48 flexible circular plots $\left(1 \mathrm{~m}^{2}\right)$. Analysis of variance and the LSD mutliple mean comparisons determined treatment differences, and stepwise multiple regression identified the important vegetation and soil variables affecting infiltration.

The control (no grazing) resulted in the highest infiltration while the treatment having the lowest residual phytomass had the lowest infiltration. Among the independent variables, standing phytomass was the most important variable affecting infiltration. Foliar and basal cover were also highly correlated to infiltration.

Key Words: infiltration rates, grazing phytomass, cover

The degree to which the grazing lands are being used by local and migratory livestock herds in Pakistan's temperate areas is of immediate concern to natural resource managers. The livestock use these ranges intensively in the growing season. As a result of heavy grazing and trampling, standing phytomass of the herbaceous and shrubby vegetation is consumed to a low level. This results in high runoff and unacceptable erosion.

Livestock grazing influences on water infiltration and runoff have long been studied. Most researchers have determined only effects of grazing use or intensity on these variables, mostly in parts of the United States. Grazing management on rangeland is based on controlling the timing, intensity, frequency, and selectivity of grazing animals (Stoddart et al. 1975). Generally, range managers recognize intensity as the most critical of these factors. Intensity determines how much vegetation remains to maintain the plant, soil, wildlife, and water components of range ecosystems. A U.S. rule of thumb with international extensions as been to take half and leave half ( $50 \%$ utilization) of the current year's growth.

Grazing influences infiltration, primarily through impacts on soil and vegetation. Heavy grazing generally decreases infiltration (Rhoades et al. 1964, Rauzi and Hanson 1966, Lusby 1970). Livestock grazing alters infiltration rates of rangeland soils by removing protective plant cover and by trampling. Vegetation and mulch cover protect the soil surface from raindrop impact and influence soil surface properties such as bulk density, organic matter content, and aggregation (Osborn 1954, Copeland 1963, Blackburn 1975, Meeuwig and Packer 1976, Blackburn et al. 1982).

Mismanagement of domestic livestock, especially with high stocking rates, has caused severe degradation in much of the

Journal Article 1568 of the New Mexico Agr. Exp. Sta., Las Cruces.

Manuscript accepted 21 Dec. 1992. world's rangelands (Bentley 1898, Box 1967, Dregne 1978). Moderate stocking rates designed to use about half the current year's forage production are generally accepted as proper grazing management (Stoddart et al. 1975), but the take-half-and-leave-half practice has several problems, especially in areas with great variation in precipitation and subsequent forage production. It is not unusual for a range to produce a few hundred kilograms per hectare one year and several times that much another year. In such a situation, the take-half-and-leave-half concept might not be the best management decision.

Liacos (1962), working on California annual grasslands, found runoff depths of $3.3 \mathrm{~cm}, 9.7 \mathrm{~cm}$, and $23.2 \mathrm{~cm}$ for ungrazed, lightly grazed and heavily grazed sites, respectively. The author attributed the increased runoff to an increase in bulk density. Sharp et al. (1964) obtained hydrologic data on Cottonwood, S.D., from small rangeland watersheds grazed lightly, moderately, and heavily. Relatively little difference in total runoff from the lightly, moderately, and heavily grazed watersheds occurred as a result of 4 runoff-producing storms. However, in 3 of the 4 storms, runoff increased markedly with increased grazing pressure. During these 3 storms, total runoff from the heavily grazed areas was about 1.5 times greater than that from moderately grazed watersheds. Runoff under light grazing was only $1 / 10$ th as great as that under heavy grazing.

Knoll and Hopkins (1959), working on blue grama (Bouteloua gracilis [Willd. ex. H.B.K.] Lang ex. Griffths) and buffalograss (Buchloe dactyloides [Nutt.] Engelm.) range near Hays, Kans., observed infiltration rates of $6.6,5.3$, and $4.0 \mathrm{~cm} \mathrm{hour}^{-1}$ on ungrazed, moderately grazed, and heavily grazed pastures, respectively. Reed and Peterson (1961) found infiltration rates on sandy and clayey soils in the northern Great Plains decreased with increased grazing intensity. Infiltration was markedly slower on buffalograss than on western wheatgrass (Elymus smithii [Rydb.] Gould) types for the heaviest- and lightest-grazed ranges. Rhoades et al. (1964), working on loamy fine sand soil in the southern Great Plains of Oklahoma, with a dominant vegetation of sand sagebrush (Artemisia filifolia Torr.) and an average canopy cover of $38 \%$, found infiltration rates were inversely proportional to the degree of continuous grazing pressure. The average stocking rates or grazing intensities were exclusion, 9 ha per animal unit (ha/AU), 7 ha/AU, and $5 \mathrm{ha} / \mathrm{AU}$ for nongrazed, lightly grazed, moderately grazed, and heavily grazed, respectively.

Rauzi (1963) conducted a study in North Dakota on an Elliott beard grass bluestem (Andropogon elliotti Chapm.), western wheatgrass, and needle-and-thread (Stipa comata Trin. \& Rupr.) community, and found the infiltration rate decreased with increasing stocking rate. Investigation showed the loss of surface cover and heavy use of livestock decreased the rate of water intake. Total water intake on the moderately grazed pasture was 1.6 times greater than that on the heaviest grazed pasture. Water intake on the ungrazed area was 1.8 times greater than that of the moderately 
grazed pasture. Dadkhah and Gifford (1980), working near Logan, Ut., found decreased infiltration rates with increased trampling percentage up to $40 \%$. Above $40 \%$ trampling, infiltration rates were no longer affected.

McCalla et al. (1984) and Thurow et al. (1986) determined the effects of livestock grazing on infiltration rates on the Edwards Plateau of Texas. They found total vegetation cover and grass standing crop were among the variables which significantly influenced infiltration rates. Weltz and Wood (1986) evaluated the influence of short duration grazing, continuous grazing, and exclusion in New Mexico. Total water infiltration in the grazed short duration pasture was half that of a continuous grazed pasture. The decrease was attributed to reduced phytomass and increased bare ground.

The main objective of this study was to determine an appropriate residual phytomass level that would protect the watershed by minimizing the runoff. The residual phytomass is assumed to be more important than the percentage utilization of annual production because of fluctuations in production from year to year. It was hypothesized that various residual phytomass levels had significantly different levels of runoff and infiltration because of the relationship between phytomass and other independent variables such as foliar and basal cover. The second objective was to determine suitable predictive equations for terminal infiltration and cumulative infiltration.

\section{Study Area}

\section{Location}

The study was conducted at Lilawani Ranch near Alpuri in the subhumid zone in northwestern Pakistan. The area lies between $34^{\circ} 31^{\prime}$ and $35^{\circ} 8 \prime \mathrm{N}$ latitude and $72^{\circ} 35^{\prime}$ and $73^{\circ} 01^{\prime} \mathrm{E}$ longitude. It is bounded on the northeast by the upper Indus Kohistan district; on the north and northwest by Malakand Agency, Swat and Swat Kohistan; on the south and southwest by Bunir subdivision; and on the southeast and east by the Indus River. The entire area forms part of the Indus River catchment. The country's largest dam, the Tarbela, has been constructed on this river. The silt accumulation rate behind this dam is so high the original estimated life span of 120 years has been reduced to 60 years. Accelerated erosion has created this problem, which in turn is the outcome of the mismanagement practiced in the high hills of the catchment area. Along with many other factors, heavy grazing is a major problem. The specific study site has been used for grazing as well as grass cutting to make hay. The same practice is common in the surrounding areas and has been since the last century. The elevation varies from 450 to 4,500 meters, and land is used mostly for agriculture and grazing. Moderate to precipitous slopes are common area features; slopes less than $30 \%$ are not common. The surface configuration is generally rugged and uneven.

\section{Rock and Soils}

The study area falls in the mountainous region of the Swat Valley. Mountains occupy most of the study area. These mountains are residual and colluvial in nature. The exposed rocks are mostly plutonic and sedimentary.

Mountainous soils are dominantly loamy and contain a variable proportion of coarse rock fragments and are mostly underlain by bedrock within $1 \mathrm{~m}$ depth. Generally, the surface soils are well humified and dark colored, and sufficiently base rich, structured, and thick to qualify for the mollic epipedon. The epipedon is more pronounced in wetter and cooler locations. The organic matter content of the surface mineral horizons varies from about $1 \%$ to more than $9 \%$, and virgin soils may contain more organic matter than their cultivated counterparts. Surface soils are weakly to moderately granular, whereas subsoils are dominantly subangular blocky. Most of the soils would be classified as mollisols. The soils in the study area have been classified as Shangla series. Because they occur on sloping surfaces, these soils are subject to active water erosion, with erosion intensity depending on the vegetational cover and slope gradient.

\section{Climate}

The study area climate is sub-humid temperate. The average minimum temperature in January in Besham is $6.7^{\circ} \mathrm{C}$, and average maximum temperature is $38.4^{\circ} \mathrm{C}$ in June. The mean minimum temperature during December and mean maximum temperature during June recorded at the Saidu Sharief Meteorological Station are $11.7^{\circ} \mathrm{C}$ and $37.7^{\circ} \mathrm{C}$, respectively.

Precipitation occurs both as rain and snow. The average monthly rainfall is $80 \mathrm{~mm}$. Snowfall generally starts by the end of November on the higher peaks and descends in December and January.

The flow of water in streams is at maximum during summer monsoon rains. The drainage rate is high and the entire area is drained by the tributaries of, or directly by, the Indus River. The most important among these tributaries is the Kana-Khurband Khuwar, which drains the Kana, Alpuri, and Lilawani valleys.

\section{Vegetation}

The study area falls in a pure blue pine (Pinus wallichiana Wall.) zone between 1,677-2,440-m elevation, which borders mixed silver fir (Abies pindrow Spash.) forests at higher elevation, while it borders pure chir pine (Pinus roxburghii Roxb.) forests on the lower side. The underwood consists of, in the lower parts, walnut (Juglans regia Linn.) bird cherry, (Prunus padus Linn.), Batangi (Pyrus pashia Ham.), amlook (Diospyros lotus Linn.), hill toon (Cedrela serrata Royle.), and horsechestnut (Aesculus indica Hiern.). The undergrowth consists of kori (Berberis lycium Royle.), gangali gulab (Rosa moschata Mill.), shadshad (Buxus sempervirens Linn.), ghoraje (Indigofera pulchella Roxb.), and chambali (Jasminum humile Linn.).

Grasses and forbs in the study area include lung (Cymbopogon iwarancusa Schult.), surmal (Heteropogon contortus Beauv.), pisholamae (Cenchrus cilaria Linn.), changae (Aristida depressa Retz.), dadum (Sorghum halepense Pers.), and khabl (Cynodon dactylon Pers.).

\section{Methods}

The data were collected for 2 growing seasons, during the summers of 1987 and 1988. A hand-portable rainfall simulator described by Wilcox et al. (1986) was used to apply rainfall to 48 flexible circular plots $\left(1 \mathrm{~m}^{2}\right)$. A single stationary nozzle was placed $200 \mathrm{~cm}$ above the center of the plot, and the application rate was $12.7 \mathrm{~cm}$ hour $^{-1}$ ). The plots were constructed from galvanized steel sheets about $15 \mathrm{~cm}$ wide and $3.54 \mathrm{~m}$ long. A small, metal runoff tray was connected to the plot to collect runoff. The soil was of such a nature that metal strips could easily be tamped into the soil without bending. The lower inside and outer side borders were sealed to prevent leakage. The soil seal was covered with a mulch layer to protect it from raindrop impact and subsequent soil particle detachment. The area of each plot was determined by a grid constructed from $1.2 \mathrm{~cm} \times 1.2-\mathrm{cm}$ mesh. Simulated rainfall was applied to each plot at the existing or antecedent soil water level for 30 minutes, and runoff collected and weighed. Plots were then covered with clear plastic to prevent evaporation and ensure fairly uniform soil water conditions for the second rainfall application. The second rainfall application was applied when the soil was still at field capacity after a lapse of 20-24 hours. Water was applied for 30 minutes during this second application. Infiltration rate was determined by subtracting runoff rate from application rate for each plot. 
Time was the cumulative period from the beginning of rainfall application. Runoff from each plot was collected at 5-minute intervals and weighed. Cumulative infiltration $(\mathrm{cm})$ was the total amount of water that infiltrated during a given application period. Surface water storage, interception loss, and evaporated water were considered to be negligible, and were not accounted for in calculating infiltration.

Standing biomass $\left(\mathrm{g} \mathrm{m}^{-2}\right)$ was determined for grasses and forbs by clipping to ground level on each plot. The litter was also hand collected. The phytomass material for each plot was placed in separate paper sacks, dried at $60-70^{\circ} \mathrm{C}$ for 48 hours, then weighed. Foliar and basal cover for each species within each plot were determined using a point sampling method (Pieper 1978). A total of 120 points were read per plot for both foliar and basal cover, using a $100-\mathrm{cm}$ wide metal frame with 20 vertical pins. Foliar cover was determined before plots were clipped, and basal cover after clipping the plots.

Antecedent soil water was calculated for 0-5 and 5-10 cm depths by the gravimetric method. Samples were collected adjacent to the runoff plots before the initial rainfall application. Bulk density was also determined at $0-3$ and $5-8 \mathrm{~cm}$ before the second rainfall application by the core method (Black 1965). After the wet run, soil samples were taken from $0-$ to $10-\mathrm{cm}$ depths for particle size and organic carbon analysis. Particle size distribution was estimated using the hydrometer method (Bouyoucos 1962). Organic carbon percentage was estimated by the Walkley-Black method (Black 1965). A micro-relief meter was used to determine soil surface roughness within each plot. Six readings (20 points each) of the micro-relief meter were taken per plot. Three readings were taken on the fall line and 3 readings perpendicular to the fall line. Mean soil depth to bedrock was also measured.

A homogenous area was subdivided into 8 plots. Within each plot, 6 subplots of $1 \mathrm{~m}^{2}$ were randomly located. Because treatments were randomly and independently alloted to the various plots, the experimental design was a completely randomized design with subsampling with 4 treatments, 2 plots per treatment and 6 subplots per plot. The treatments were 4 different residual phytomass levels. In year 1 , treatments $1,2,3$, and 4 had a residual phytomass of $2,667,1,432,1,020$ and $627 \mathrm{~kg} \mathrm{ha}^{-1}$, while in year 2 , the residual phytomass levels were $3,382,1,443,1,037$, and $620 \mathrm{~kg} \mathrm{ha}^{-1}$ for treatment $1,2,3$, and 4 , respectively. Treatment 1 was not grazed and represented the potential phytomass each year. The remaining residual phytomass levels were achieved by allowing grazing in the plots until the desired levels were achieved. The treatments were not equally spaced and, therefore, were considered nonstructured.

The data for each year were analyzed separately. Overall differences among treatments were tested using analysis of variance by the General Linear Model procedure (SAS Institute 1985). If the analysis of variance F-test was significant, a protected Fisher's Least Significance Difference (LSD) was used to separate means at $0.01,0.05,0.01$ and 0.20 significance levels. Stepwise multiple regression was used to select the highest correlated vegetation and soil variables influencing infiltration.

\section{Results and Discussion}

In the first year, natural rainfall was less than the long-term average, resulting in the low ungrazed phytomass production of $2,667 \mathrm{~kg} \mathrm{ha}^{-1}$ as compared to the second year of $3,382 \mathrm{~kg} \mathrm{ha}^{-1}$. The remaining residual levels were kept nearly the same in both years. Table 1 shows the potential phytomass of both years and the various residual phytomass levels achieved after grazing. Although the percentages of total phytomass are different, the residual levels are nearly the same in both years, except for the control. These levels were chosen because they generally represent moderate, heavy, and very heavy grazing.
Table 1. Percentage residual phytomass.

\begin{tabular}{|c|c|c|c|c|}
\hline \multirow[b]{2}{*}{ Treatment } & \multicolumn{2}{|c|}{ Year 1} & \multicolumn{2}{|c|}{ Year 2} \\
\hline & Phytomass & $\begin{array}{l}\text { Percentage } \\
\text { of total }\end{array}$ & Phytomass & $\begin{array}{c}\text { Percentage } \\
\text { of total }\end{array}$ \\
\hline & $\mathrm{kg} \mathrm{ha}^{-1}$ & & $\mathrm{~kg} \mathrm{ha}^{-1}$ & \\
\hline 1 & $2667(7.79)^{t}$ & 100 & $3382(18.27)$ & 100 \\
\hline 2 & $1432(9.72)$ & 54 & $1443 \quad(5.57)$ & 43 \\
\hline 3 & $1020(3.79)$ & 38 & $1037 \quad(3.18)$ & 31 \\
\hline 4 & $627(4.52)$ & 24 & $620(3.47)$ & 18 \\
\hline
\end{tabular}

'Standard error (SE) is given in the parenthesis for the phytomass.

\section{Terminal Infiltration}

Terminal infiltration rate is an important statistic in the infiltration process. At this level, the infiltration rate becomes almost constant and a fixed quantity of water enters through the soil surface. In the experiment, the constant terminal infiltration rate was obtained within 30 minutes of applying simulated rainfall. In year 1 at the antecedent soil water level, the F-value was 7.37 and the p-value was 0.0416 , while with soil water near field capacity, these values were 3.62 and 0.1232 , respectively. In year 2 , the F-value and p-value were 32.18 and 0.0019 at the antecedent soil water level, while these values were 26.32 and 0.0043 for soil water near field capacity, respectively. In general, p-values are less than the 0.05 level of probability. Treatment comparisons are shown for terminal infiltration for both years in Tables 2 and 3.

Table 2. Treatment comparisons for terminal infiltration rates at the antecedent soil water level and near field capacity for year 1 .

\begin{tabular}{|c|c|c|c|c|c|c|}
\hline \multirow[b]{2}{*}{ Treatment } & \multirow{2}{*}{$\begin{array}{l}\text { Phyto- } \\
\text { mass }\end{array}$} & \multirow{2}{*}{$\begin{array}{c}\text { Infiltra- } \\
\text { tion }\end{array}$} & \multicolumn{4}{|c|}{ Level of significance $^{-1}$} \\
\hline & & & 0.01 & 0.05 & 0.10 & 0.20 \\
\hline \multicolumn{7}{|c|}{$\begin{array}{l}\left(\mathrm{kg} \mathrm{ha}^{-1}\right)\left(\mathrm{cm} \mathrm{hr}^{-1}\right) \\
\text { A. Antecedent soil water } \\
\end{array}$} \\
\hline $\begin{array}{l}1 \\
2 \\
3 \\
4\end{array}$ & $\begin{array}{r}2667 \\
1432 \\
1020 \\
627\end{array}$ & $\begin{array}{l}5.22 \\
4.62 \\
4.35 \\
3.66\end{array}$ & $\begin{array}{l}\mathbf{a} \\
\mathbf{a} \\
\mathbf{a} \\
\mathbf{a}\end{array}$ & $\begin{array}{l}a \\
a \\
a b \\
b\end{array}$ & $\begin{array}{l}a \\
a b \\
b c \\
c\end{array}$ & $\begin{array}{l}a \\
b \\
b \\
c\end{array}$ \\
\hline \multicolumn{7}{|c|}{ B. Soil water near field capacity } \\
\hline $\begin{array}{l}1 \\
2 \\
3 \\
4\end{array}$ & $\begin{array}{r}2667 \\
1432 \\
1020 \\
627\end{array}$ & $\begin{array}{l}4.63 \\
3.60 \\
3.10 \\
2.58\end{array}$ & $\begin{array}{l}a \\
a \\
a \\
a\end{array}$ & $\begin{array}{l}\mathbf{a} \\
\mathbf{a b} \\
\mathbf{a b} \\
\mathbf{b}\end{array}$ & $\begin{array}{l}\mathbf{a} \\
\mathbf{a b} \\
\mathbf{b} \\
\mathbf{b}\end{array}$ & $\begin{array}{l}a \\
b \\
b c \\
c\end{array}$ \\
\hline
\end{tabular}

'Means followed by the same letter within a soil water condition are not significantly different.

2Overall analysis of variance $F(3,4)=7.37, p=0.0416$ for dry run.

Overall analysis of variance $F(3,4)=3.62, p=0.1232$ for wet run.

Terminal infiltration rates were highest in treatment 1 , representing no utilization and a potential phytomass of $2,667 \mathrm{~kg} \mathrm{ha}^{-1}$ and $3,382 \mathrm{~kg} \mathrm{ha}^{-1}$ for years 1 and 2 , respectively. The difference in mean terminal infiltration was much greater between treatment 1 and the rest of the treatments. This is probably because treatment 1 had a greater difference in residual phytomass compared to differences among the other treatments.

Infiltration rate near field capacity was lower than for antecedent soil water conditions in both years, and the difference in the means at soil water near field capacity was greater. This is attributed to the importance of antecedent soil water condition in the infiltration process. Infiltration rates are usually negatively correlated with soil water content. The soil water content was lower at the antecedent soil water condition; therefore, terminal infiltration rates are higher at antecedent soil water conditions than soil water near field capacity. However, the trend near field capacity is more important than at the antecedent soil water level. The effects of 
Table 3. Treatment comparisons for terminal infiltration rates at the antecedent soil water level and near field capacity for year 2.

\begin{tabular}{|c|c|c|c|c|c|c|}
\hline \multirow[b]{2}{*}{ Treatment } & \multirow{2}{*}{$\begin{array}{l}\text { Phyto- } \\
\text { mass }\end{array}$} & \multirow{2}{*}{$\begin{array}{l}\text { Infiltra- } \\
\text { tion }\end{array}$} & \multicolumn{4}{|c|}{ Level of significance $^{-1}$} \\
\hline & & & 0.01 & 0.05 & 0.10 & 0.20 \\
\hline \multicolumn{7}{|c|}{$\begin{array}{l}\left(\mathrm{kg} \mathrm{ha}^{-1}\right)\left(\mathrm{cm} \mathrm{hr}^{-1}\right) \\
\text { A. Antecedent soil water } \\
\end{array}$} \\
\hline $\begin{array}{l}1 \\
2 \\
3 \\
4\end{array}$ & $\begin{array}{r}3882 \\
1443 \\
1037 \\
620\end{array}$ & $\begin{array}{l}6.81 \\
4.49 \\
3.36 \\
2.52\end{array}$ & $\begin{array}{l}\mathbf{a} \\
\mathbf{b} \\
\mathbf{b} \\
\mathbf{b}\end{array}$ & $\begin{array}{l}a \\
b \\
b c \\
c\end{array}$ & $\begin{array}{l}\text { a } \\
\text { b } \\
\text { c } \\
\text { c }\end{array}$ & $\begin{array}{l}a \\
b \\
c \\
d\end{array}$ \\
\hline \multicolumn{7}{|c|}{ B. Soil water near field capacity ${ }^{3}$} \\
\hline $\begin{array}{l}1 \\
2 \\
3 \\
4\end{array}$ & $\begin{array}{r}3882 \\
1443 \\
1037 \\
620\end{array}$ & $\begin{array}{l}6.20 \\
4.43 \\
2.30 \\
0.92\end{array}$ & $\begin{array}{l}a \\
a b \\
b c \\
c\end{array}$ & $\begin{array}{l}a \\
a \\
b \\
b\end{array}$ & $\begin{array}{l}a \\
b \\
c \\
d\end{array}$ & $\begin{array}{l}a \\
b \\
c \\
d\end{array}$ \\
\hline
\end{tabular}

'Means followed by the same letter within a soil water condition are not significantly different.

${ }^{2}$ Overall analysis of variance $F(3,4)=32.18, p=0.029$ for dry run.

${ }^{3}$ Overall analysis of variance $F(3,4)=26.32, p=0.0043$ for wet run.

antecedent soil water condition can prevail for a shorter duration than at field capacity if the rainfall duration is greater.

Treatment means for both years at each soil water condition were in descending order from treatment 1 to treatment 4 . A decrease in the phytomass level resulted in a corresponding decrease in terminal infiltration, which implies the residual phytomass can be used to reflect infiltration rates.

Orthogonal polynomial analysis was used to evaluate the linear, quadratic, and cubic effects for terminal infiltration. The linear effect was significant for year 1 at both soil water conditions. In year 2, only a linear effect was significant at antecedent soil water, while linear, as well as quadratic effects, were significant at soil water near field capacity. No cubic effect was significant in any year for any soil water level at the 0.10 level of significance.

\section{Cumulative Infiltration}

Cumulative infiltration is the total quantity of water absorbed through the soil surface during $\mathbf{3 0}$ minutes of simulated rainfall. During year 1 , the $F$ and p-values were 3.94 and 0.109 for soil water at antecedent level, while these values for soil water at field capacity were 6.38 and 0.053 , respectively. During year 2 , the $F$ and p-values were 21.92 and 0.006 at antecedent soil water, these values were 18.58 and 0.008 , respectively, for wet run.

Treatment 1 (exclosure) had the highest cumulative infiltration and treatment 4 had the lowest cumulative infiltration in both years (Tables 4 and 5). This was probably the result of the higher residual phytomass in treatment 1 as compared to treatment 4 . Phytomass was positively correlated with infiltration rates; therefore, treatment 1 resulted in the highest cumulative infiltration.

The difference between the cumulative infiltration means is greater between treatment 1 and treatment 2, compared to the difference among 2,3 , and 4 . This is probably the result of differences in residual phytomass levels. This clearly supports the relationship between residual phytomass and cumulative infiltration. Overall, infiltration for treatment 1 was significantly different from that for the rest of the treatments at $0.05,0.10$, and 0.20 probability levels, as shown in Tables 4 and at all probability levels in Table 5 . Orthogonal polynomials were used to examine the linear, quadratic, and cubic effects. The linear effect was significant, but no other effect was significant at 0.10 significance level at any soil water condition in any year.

\section{Predictive Equations}

Much hydrology research is devoted to modeling to describe how variables are related. A useful method of modeling the rela-
Table 4. Treatment comparisons for cumulative infiltration rates at the antecedent soil water level and near field capacity for year 1.

\begin{tabular}{|c|c|c|c|c|c|c|}
\hline \multirow[b]{2}{*}{ Treatment } & \multirow{2}{*}{$\begin{array}{l}\text { Phyto- } \\
\text { mass }\end{array}$} & \multirow{2}{*}{$\begin{array}{l}\text { Infiltra- } \\
\text { tion }\end{array}$} & \multicolumn{4}{|c|}{ Level of significance ${ }^{-1}$} \\
\hline & & & 0.01 & 0.05 & 0.10 & 0.20 \\
\hline \multicolumn{7}{|c|}{$\begin{array}{l}\left(\mathrm{kg} \mathrm{ha}^{-1}\right)\left(\mathrm{cm} \mathrm{hr}^{-1}\right) \\
\text { A. Antecedent soil water }\end{array}$} \\
\hline $\begin{array}{l}1 \\
2 \\
3 \\
4\end{array}$ & $\begin{array}{r}2667 \\
1432 \\
1020 \\
627\end{array}$ & $\begin{array}{l}7.16 \\
5.84 \\
5.41 \\
4.61\end{array}$ & $\begin{array}{l}a \\
a \\
a \\
a\end{array}$ & $\begin{array}{l}\mathbf{a} \\
\mathbf{a b} \\
\mathbf{a b} \\
\mathbf{b}\end{array}$ & $\begin{array}{l}a \\
\mathbf{a b} \\
\mathbf{b} \\
\mathrm{b}\end{array}$ & $\begin{array}{l}a \\
b \\
b c \\
c\end{array}$ \\
\hline \multicolumn{7}{|c|}{ B. Soil water near field capacity ${ }^{3}$} \\
\hline $\begin{array}{l}1 \\
2 \\
3 \\
4\end{array}$ & $\begin{array}{r}2667 \\
1432 \\
1020 \\
627\end{array}$ & $\begin{array}{l}6.04 \\
4.30 \\
4.05 \\
3.36\end{array}$ & $\begin{array}{l}\text { a } \\
\text { a } \\
\text { a } \\
\text { a }\end{array}$ & $\begin{array}{l}\mathbf{a} \\
\mathbf{a b} \\
\mathbf{b} \\
\mathbf{b}\end{array}$ & $\begin{array}{l}a \\
b \\
b \\
b\end{array}$ & $\begin{array}{l}\mathbf{a} \\
\mathbf{b} \\
\mathbf{b} \\
\mathbf{b}\end{array}$ \\
\hline
\end{tabular}

1 Means followed by the same letter within a soil water condition are not significantly different.

different.

Overall analysis of variance $F(3,4)=6.38, p=0.053$ for wet run.

Table 5. Treatment comparisons for cumulative infiltration at the antecedent soil water level and near field capacity for year 2 .

\begin{tabular}{|c|c|c|c|c|c|c|}
\hline \multirow[b]{2}{*}{ Treatment } & \multirow{2}{*}{$\begin{array}{l}\text { Phyto- } \\
\text { mass }\end{array}$} & \multirow{2}{*}{$\begin{array}{l}\text { Infiltra- } \\
\text { tion }\end{array}$} & \multicolumn{4}{|c|}{ Level of significance $^{-1}$} \\
\hline & & & 0.01 & 0.05 & 0.10 & 0.20 \\
\hline \multicolumn{7}{|c|}{$\begin{array}{l}\quad\left(\mathrm{kg} \mathrm{ha}^{-1}\right)\left(\mathrm{cm} \mathrm{hr}^{-1}\right) \\
\text { A. Antecedent soil water } \\
\end{array}$} \\
\hline $\begin{array}{l}1 \\
2 \\
3 \\
4\end{array}$ & $\begin{array}{r}3382 \\
1443 \\
1037 \\
620\end{array}$ & $\begin{array}{l}7.65 \\
5.67 \\
4.57 \\
3.99\end{array}$ & $\begin{array}{l}a \\
a b \\
b \\
b\end{array}$ & $\begin{array}{l}a \\
b \\
b c \\
c\end{array}$ & $\begin{array}{l}a \\
b \\
c \\
c\end{array}$ & $\begin{array}{l}\mathbf{a} \\
\mathbf{b} \\
\mathbf{c} \\
\mathbf{c}\end{array}$ \\
\hline \multicolumn{7}{|c|}{ B. Soil water near field capacity ${ }^{3}$} \\
\hline $\begin{array}{l}1 \\
2 \\
3 \\
4\end{array}$ & $\begin{array}{r}3382 \\
1443 \\
1037 \\
620\end{array}$ & $\begin{array}{l}6.89 \\
3.97 \\
3.09 \\
2.96\end{array}$ & $\begin{array}{l}\mathbf{a} \\
\mathbf{b} \\
\mathbf{b} \\
\mathbf{b}\end{array}$ & $\begin{array}{l}a \\
b \\
b \\
b\end{array}$ & $\begin{array}{l}a \\
b \\
b \\
b\end{array}$ & $\begin{array}{l}\mathbf{a} \\
\mathbf{b} \\
\mathbf{b} \\
\mathbf{c}\end{array}$ \\
\hline
\end{tabular}

Means followed by the same letter within a soil water condition are not significantly different.

${ }^{2}$ Overall analysis of variance $F(3,4)=21.92, p=0.006$ for dry run.

${ }^{3}$ Overall analysis of variance $F(3,4)=18.58, p=0.0008$ for wet run.

tionship between the variables is regression analysis.

The regression equations are of the following general form:

$$
\hat{Y}=\mathbf{a}+\mathrm{b} 1 \mathrm{X} 1+\ldots \ldots \ldots . . . \mathrm{bn} X \mathrm{Xn}
$$

where $Y$ is the predicted dependent variable, $a$ is the $y$-intercept, $b$ is the estimated regression coefficient, and $X$ is the independent variable influencing $\hat{Y}$. The predictive equations also identify the most important variables influencing a given dependent variable. The dry data for years 1 and 2 were combined and the wet data for years 1 and 2 were combined. A significance level of 0.15 was chosen for an independent variable to be included in the model. The regression equations are shown in Tables 6-7.

The predictive equation for terminal infiltration rate $\left(\mathrm{cm} \mathrm{hr}^{-1}\right)$ for both years at the antecedent soil water level (Table 6) was:

$$
\mathrm{Y}_{1}=2.046+0.012(\mathrm{X} 1)+0.042(\mathrm{X} 9)-0.026(\mathrm{X} 12)
$$

Where $X 1$ is standing phytomass, $X 9$ is soil depth, and $X 12$ is soil water from $0-5 \mathrm{~cm}$ depth. The overall $F$ and $R^{2}$ for the selected model are 28.19 and 0.52 , respectively.

The predictive equation for terminal infiltration for both the years at soil water near field capacity (Table 6) was:

$$
\hat{Y}=2.056+0.011(\mathrm{X} 1)-0.044(\mathrm{X} 4)
$$


Table 6. Multiple regression equations for total terminal infiltration for year 1 and year 2 with combined soil water conditions.

\begin{tabular}{llc}
\hline \hline $\begin{array}{l}\text { Year and } \\
\text { condition }\end{array}$ & Regression equations & $R^{2}$ \\
\hline 1987 and & $Y 1=2.046+0.012(\mathrm{X} 1)+0.042(\mathrm{X} 9)-0.026(\mathrm{X} 12)$ & 0.52 \\
1988 dry $^{3}$ & $(\mathrm{se}=0.001)^{2}(\mathrm{se}=0.025)(\mathrm{se}=0.013)$ & \\
& $\begin{array}{l}(\mathrm{p}=0.0001)(\mathrm{p}=0.098)(\mathrm{p}=0.051) \\
1987 \text { and }\end{array}$ & $\begin{array}{l}\mathrm{Y} 2=2.056+0.011(\mathrm{X} 1)-0.044(\mathrm{X} 4) \\
(\mathrm{se}=0.002)(\mathrm{se}=0.020)\end{array}$ \\
1988 wet $^{3}$ & $\begin{array}{l}(\mathrm{p}=0.001)(\mathrm{p}=0.033) \\
\end{array}$ & \\
\hline
\end{tabular}

'Sample size $(n)=96$.

2Standard error and p-value for each regression coefficient have been given in parenthesis for each column, respectively.

$\mathrm{X} 1=$ Standing phytomass $\left(\mathrm{g} \mathrm{m}^{2}\right)$

$\mathrm{X} 4=$ Litter cover associated with foliar cover $(\%)$

X9 = Soil depth $(\mathrm{cm})$

$\mathrm{X} 12$ = Soil water $(0-5 \mathrm{~cm})$ depth, dry $(\%)$

Overall analysis of variance $F(3,77)=28.19, p=0.0001$ for year 1 and year 2 , dry. Overall analysis of variance $F(2,77)=30.35, \mathrm{p}=0.0001$ for year 1 and year 2 , wet.

Table 7. Multiple regression equations for cumulative infiltration for year 1 and year 2 with combined soil water conditions 1 .

\begin{tabular}{llc}
\hline \hline $\begin{array}{l}\text { Year and } \\
\text { condition }\end{array}$ & Regression equations & $R^{2}$ \\
\hline 1987 and & $\begin{array}{l}\hat{Y} 3=3.398+0.011(\mathrm{X} 1)+0.034(\mathrm{X} 9)-0.017(\mathrm{X} 12) \\
(\mathrm{se}=0.001)^{2}(\mathrm{se}=0.021)(\mathrm{se}=0.011)\end{array}$ & 0.52 \\
1988 dry $^{3}$ & $\begin{array}{l}(\mathrm{p}=0.0001)(\mathrm{p}=0.010)(\mathrm{p}=0.138) \\
1987 \text { and }\end{array}$ & $\begin{array}{l}\mathrm{Y} 4=2.362+0.013(\mathrm{X} 1) \\
(\mathrm{se}=0.001)\end{array}$ \\
$\begin{array}{l}(\mathrm{p}=0.0001) \\
\text { wet }^{3}\end{array}$ & 0.51 \\
\hline
\end{tabular}

'Sample size $(n)=96$.

2 Standard error and $p$-value for each regression coefficient have been given in parenthesis for each column, respectively.

$\mathrm{X} 1=$ Standing phytomass $\left(\mathrm{g} \mathrm{m}^{2}\right)$

$\mathrm{X} 9=$ Soil depth $(\mathrm{cm})$

$X 12=$ Soil water $(0-5 \mathrm{~cm})$ depth, dry $(\%)$

${ }^{3}$ Overall analysis of variance $F(3,82)=29.07, p=0.0001$ for year 1 and year 2 , dry.

Overall analysis of variance $F(1,83)=88.52, p=0.0001$ for year 1 and year 2 , wet.

Where $\mathrm{X} 1$ is standing phytomass and $\mathrm{X} 4$ is litter cover associated with foliar cover. The overall $F$ and $R^{2}$ are 30.35 and 0.44 , respectively.

In general, standing phytomass, foliar cover and basal cover were the variables included in most of the models, and are important from a management point of view. The best model would be the one with most of these variables and high $R^{2}$ and F-values, with a low standard error and a low p-value.

\section{Cumulative Infiltration}

Cumulative infiltration equations are also important in hydrology. These equations help to identify the important variables that affect cumulative infiltration (Table 7).

The predictive equation for cumulative infiltration rate $\left(\mathrm{cm} \mathrm{hr}^{-1}\right)$ for the combined data of year 1 and year 2 at antecedent soil water (Table 7) was:

$$
\mathrm{Y}=3.398+0.011(\mathrm{X} 1)+0.034(\mathrm{X} 9)-0.017(\mathrm{X} 12)
$$

Where $\mathrm{X} 1$ is standing phytomass, $\mathrm{X} 9$ is soil depth, and $\mathrm{X} 12$ is soil water $0-5 \mathrm{~cm}$ depth. The overall $\mathrm{F}$ and $R^{2}$ for the selected model are 29.07 and 0.52 , respectively.

The predictive equation for cumulative infiltration rate $\left(\mathrm{cm} \mathrm{hr}^{-1}\right)$ for the combined data for year 1 and year 2 at soil water near field capacity (Table 7) was:

$$
\hat{Y} 4=2.362+0.013(\mathrm{X} 1)
$$

Where $\mathrm{X} 1$ is standing phtyomass. The overall $\mathrm{F}$ and $R^{2}$ for the selected model are 88.52 and 0.51 , respectively.

\section{Summary and Conclusions}

Like many other parts of the world, most Pakistan rangelands are overgrazed. Overgrazed rangelands not only affect the on-site productivity, but also negatively affect water quality and siltation of reservoirs. In Pakistan, moist temperate ranges are under heavy grazing pressure by local livestock and nomadic herds. The main reason for the deterioration is the lack of knowledge and poor socio-economic conditions of the people, and the lack of research, which leads to overgrazing.

To determine the severity of the runoff erosion caused by livestock grazing and to determine a reasonably good residual phytomass level both for livestock production, as well as to maintain and improve the watershed condition, this experiment was conducted in the temperate ranges of northwestern Pakistan. The experiment was continued for 2 growing seasons. The following conclusions are drawn from the results of this study:

1) Residual phytomass significantly affects infiltration rates.

2) The exclosure or no grazing treatment resulted in the highest infiltration rates among all the treatments.

3) The treatment with the lowest residual phytomass resulted in the lowest infiltration rates.

4) To protect and maintain the range sites, and for watershed management, at least $1,000-1,400 \mathrm{~kg} \mathrm{ha}^{-1}$ residual phytomass must be retained.

5) The potential phytomass changes from year to year; therefore, the watershed manager should rely on the residual phytomass level rather than removing a fixed percentage of forage.

In general, the decreased terminal and cumulative infiltration indicate treatment 4 was the least desirable condition of any of the grazing treatments, followed by treatments 3 and 2 . Treatment 1 had the highest measured infiltration rates, but is not practical from the standpoint of livestock production.

To increase infiltration, one must consider a suitable residual phytomass level, which has a direct effect on this process. Although the exclosure (treatment 1) resulted in the highest infiltration rates, and is also most desirable from a watershed point of view, cultural and economic demands will not allow $100 \%$ protection of the phytomass. On the other hand, the lowest phytomass level of treatment 4 resulted in the lowest infiltration, and is not desirable for watershed protection. Thus, the land manager is left with treatment 2 and treatment 3 , out of which to choose the residual phytomass level that will ensure proper utilization of the resource and proper protection of the watershed condition.

The choice for a given treatment will vary from site to site, and is greatly dependent on the major management objectives. If a range site is situated in a greatly disturbed riparian area, treatment 1 may be recommended for quick restoration. Similarly, if the range condition is good and there is great demand for forage, treatment 4 can also be recommended. In our view, the best choice would be treatment 2 or 3 , rather than choosing the extremes. This helps assume high infiltration and will not adversely affect livestock production.

\section{Literature Cited}

Bentley, H.L. 1898. Cattle ranges of the Southwest: A history of exhaustion of pasturage and suggestions for its restoration. USDA Farmers Bull. 72.

Black, C.A. 1965. Methods of soil analysis. Amer. Soc. Agron. Series 9. Madison, Wis.

Blackburn, W.H. 1975. Factors influencing infiltration and sediment production of semiarid rangelands in Nevada. Water Resource. Res. 11:929-937.

Blackburn, W.H., R.W. Knight, and M.K. Wood. 1982. Impacts of grazing on watersheds. Texas Agr. Exp. Sta. MP 1496. 
Bouyoucos, G.J. 1962. Hydrometer method improved for making particle size analysis of soil. Agron. J. 54:464-465.

Box, T.W. 1967. Range deterioration in west Texas. Southwestern Historical Quart. 9:37-45.

Copeland, O.L., Jr. 1963. Land use and ecological factors in relation to sediment yields. In: Proc., Fed. Interagency Sedimentation Conf., USDA Misc. Pub. 980:72-84.

Dregne, H.E. 1978. Desertification: Man's abuse of the land. J. Soil and Water Conserv. 33:11-14.

Dadkhah, M., and G.F. Gifford. 1980. Influence of vegetation, rock cover and trampling on infiltration rates and sediment production. Water Resource Bull. 16:979-985.

Knoll, G., and H.H. Hopkins. 1959. The effect of grazing and trampling upon certain soil properties. Trans. Kansas Acad. Sci. 62:221-231.

Liacos, L.G. 1962. Water yield as influenced by degree of grazing in the California winter grasslands. J. Range Manage. 15:34-42.

I.ushy, F.C. 1970. Hydrologic and biotic effects of grazing versus nongra7ing near Grand Junction, Colorado. J. Range Manage. 23:256-260.

McCalla, G.R., W.H. Blackburn, and L.B. Merrill. 1984. Effects of livestock grazing on infiltration rates, Edwards Plateau of Texas. J. Range Manage. 37:265-268.

Meeuwig, R.o., and P.E. Packer. 1976. Erosion and runoff on forest and rangelands. p. 106-116. In: Proc. of the Fifth Workshop of the United States/Australia Rangelands Panel, Boise, Ida. June 15-22. 1975.

Osburn, B. 1954. Soil splash by raindrop impact on bare soils. J. Soil and Water Conser. 9:33-38.
Pieper, R.D. 1978. Measurement techniques for herbaceous and shrubby vegetation. New Mexico State Univ., Las Cruces.

Rauzi, F. 1963. Water intake and plant composition as affected by differential grazing on rangeland. J. Soil and Water Conserv. 18:114-116.

Rauzi, F., and C.L. Hanson. 1966. Water intake and runoff as affected by intensity of grazing. J. Range Manage. 19:351-356.

Reed, M.J., and R.A. Peterson. 1961. Vegetation, soils and cattle responses to grazing on northern Great Plains Range. USDA, Bull. 1252.

Rhoades, E.P., L.F. Locke, H.M. Taylor, and E.H. McIlvain. 1964. Water intake on sandy range as affected by twenty years of differential cattle stocking rates. J. Range Manage. 17:185-190.

SAS Institute, Inc. 1985. SAS User's Guide: Statistics, Version 5 Edition. Cary, N.C.: SAS Institute, Inc., 1985.

Sharp, A.L., J.J. Bond, J.W. Neubergen, A.R. Kuhiman, and J.K. Lewis. 1964. Runoff as affected by intensity of grazing on rangeland. J. Soil and Water Conserv. 19:103-106.

Stoddart, L.A., A.D. Smith, and T.W. Box. 1975. Range management. McGraw-Hill Book Co., N.Y.

Thurow, T.L., W.H. Blackburn, and C.A. Taylor. 1986. Hydrologic characteristics of vegetation types as affected by livestock grazing systems, Edwards Plateau, Texas. J. Range Manage. 39:505-509.

Weltz, M., and M.K. Wood. 1986. Short duration grazing in central New Mexico: effects on infiltration rates. J. Range Manage. 39:365-368.

Wilcox, B.P., M.K. Wood, J.T. Tromble, and T.J. Ward. 1986. A hand portable single nozzle rainfall simulator designed for use on steep slopes. J. Range Manage. 39:375-377.

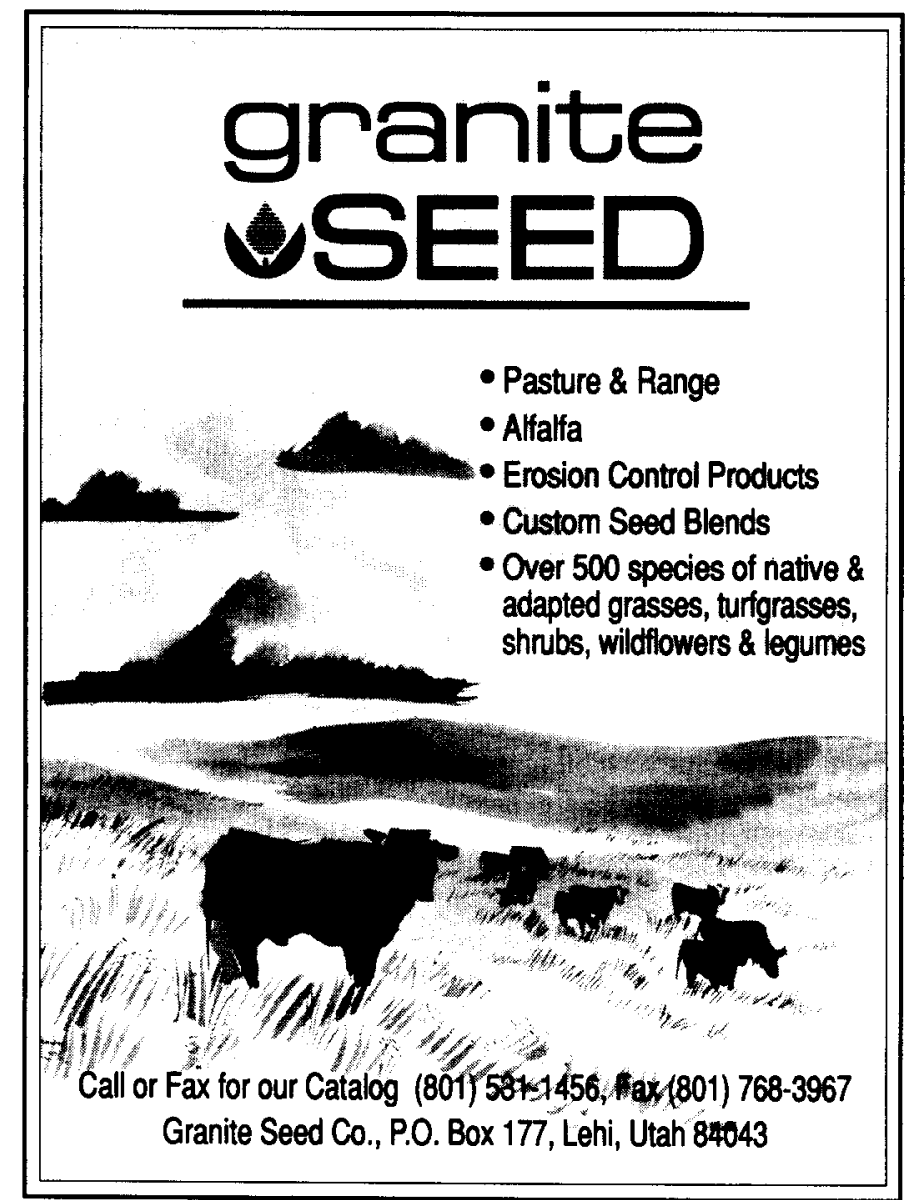

